\title{
SUSTAINABILITY APPROACH IN THE CONTEXT OF FLOOD RISK MANAGEMENT
}

\author{
K. Todorova* \\ Faculty of Natural Resource Economics, University of National and World Economy, Sofia, Bulgaria
}

\begin{abstract}
The current policy-making on EU level in the field of water resource conservation and flood risk management displays tendency in applying sustainability approach for water status improvement, water scarcity and droughts, as well as reduction of disasters. The appearance of floods as natural disasters is associated mainly with community vulnerability to adverse effects of a natural hazard. Therefore, reducing vulnerability is a key element in flood risk management. Finding the proper approach, which could embrace the interconnected elements in a system, such as human society and the surrounding nature, is more than necessary. Currently, the prevalent method worldwide for flood management is oriented towards the so called "hard engineering" measures, including dams, channelization, etc. Therefore, it is critically to consider expanding the current measures including natural water retention measures for flood control, measures against erosion along the river catchment, afforestation, etc. In this paper the opportunities for the enforcement of sustainability flood risk management approach in the country will be analyzed. Suggestions for improvement will be presented as a conclusion.
\end{abstract}

Key words: sustainable flood risk management, natural water retention measures

\section{INTRODUCTION}

Floods as natural disasters appear only when society has been exposed to the catastrophic event and its capability to manage the event has been decreased. Managing vulnerability in sustainable manner and recognizing probability of such event can lead to diminished flood risk. Ecosystem services which have natural regulation role in the context of flood management are one of the major indicators for stability of a natural system. When natural way for regulating floods has been demolished through structural manmade engineering works, society vulnerability grows proportionally. Flood risk management should work with nature, rather than against it (1). Therefore, putting focus on sustainable flood risk management and choosing natural measures will inevitably lead to increased system resilience, e.g. society, nature and economy.

\section{EU POLICY GRASPING SUSTAINABILITY}

It has been obvious that in recent years the

\footnotetext{
*Correspondence to: Kristina Todorova, Faculty of Natural Resource Economics, University of National and World Economy, Sofia, Bulgaria, +359887599159, ktodorova@unwe.bg
}

objective of sustainable development has been implemented into a broad range of policies (2). Sustainability approach introduces new paradigm of thinking taking into account the main spheres in our life - the natural environment, the economy and the society. As Brutland's report "Our Common Future" stated in 1987: "Sustainable development is development that meets the needs of the present without compromising the ability of future generations to meet their own needs...... Development involves a progressive transformation of economy and society". Sustainability has pushed its way through major policies in European Union, as well as other developed countries, but still the efforts needed for this "progressive transformation" are insufficient.

In the context of flood risk management the sustainability approach has been implemented recently trough the Floods Directive $2007 / 60 / \mathrm{EU}$. Its main aim is to build a framework for assessment and management of flood risk. Currently, on EU level, the member states are obliged to provide Flood Risk Management Plans until the end of 2015. Their objective is to diminish the probability of catastrophic events and to reduce vulnerability of the society, economic activity, natural environment and cultural heritage. Together 
with the new River Basin Management Plans, they represent integrated water management which is a starting point in introducing sustainable approach in flood risk management.
FLOOD VULNERABILITY

TODOROVA K.

The main triggers for floods in Europe have been studied during the last decades. Yet, the main reasons appear to be very complex and mutually reinforcing. The following could be listed as more important (Figure 1).

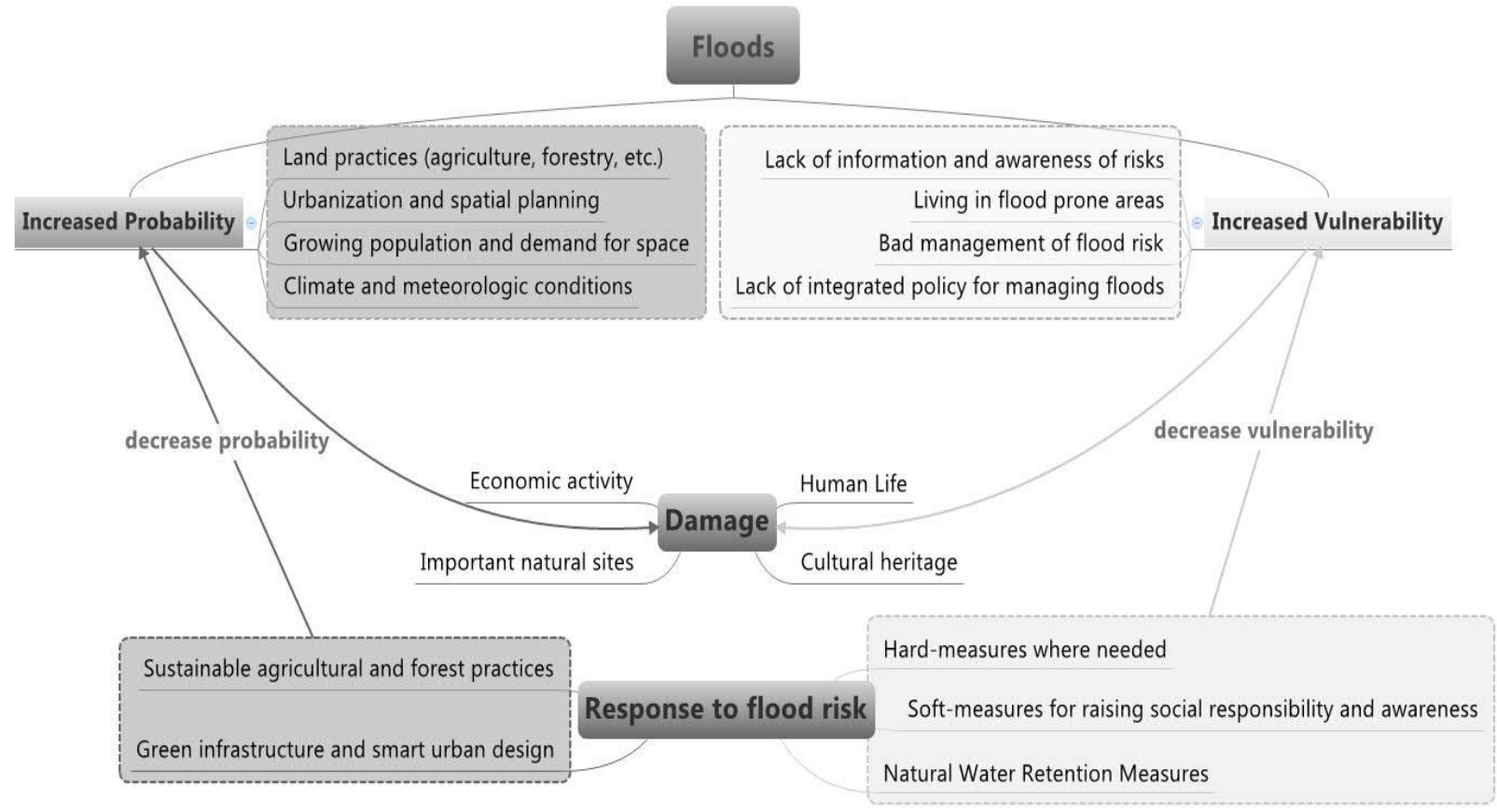

Figure 1. Triggers, consequences, response to floods

During the last decade several major floods took place. The years 2005, 2006, 2010 and 2013 appear to be the ones with most floods. As it can be seen from the Figure $\mathbf{1}$ and $\mathbf{2}$ in the period of 2003-2008 and 2010-2013 the most common natural disaster are floods, followed by landslides and storms.

\begin{tabular}{|l|c|c|c|c|c|c|c|}
\hline \multicolumn{7}{|c|}{} & \multicolumn{7}{|c|}{} \\
\hline & \multicolumn{7}{|c|}{} \\
\hline
\end{tabular}

Figure 2. Natural disasters by type 2003-2008 


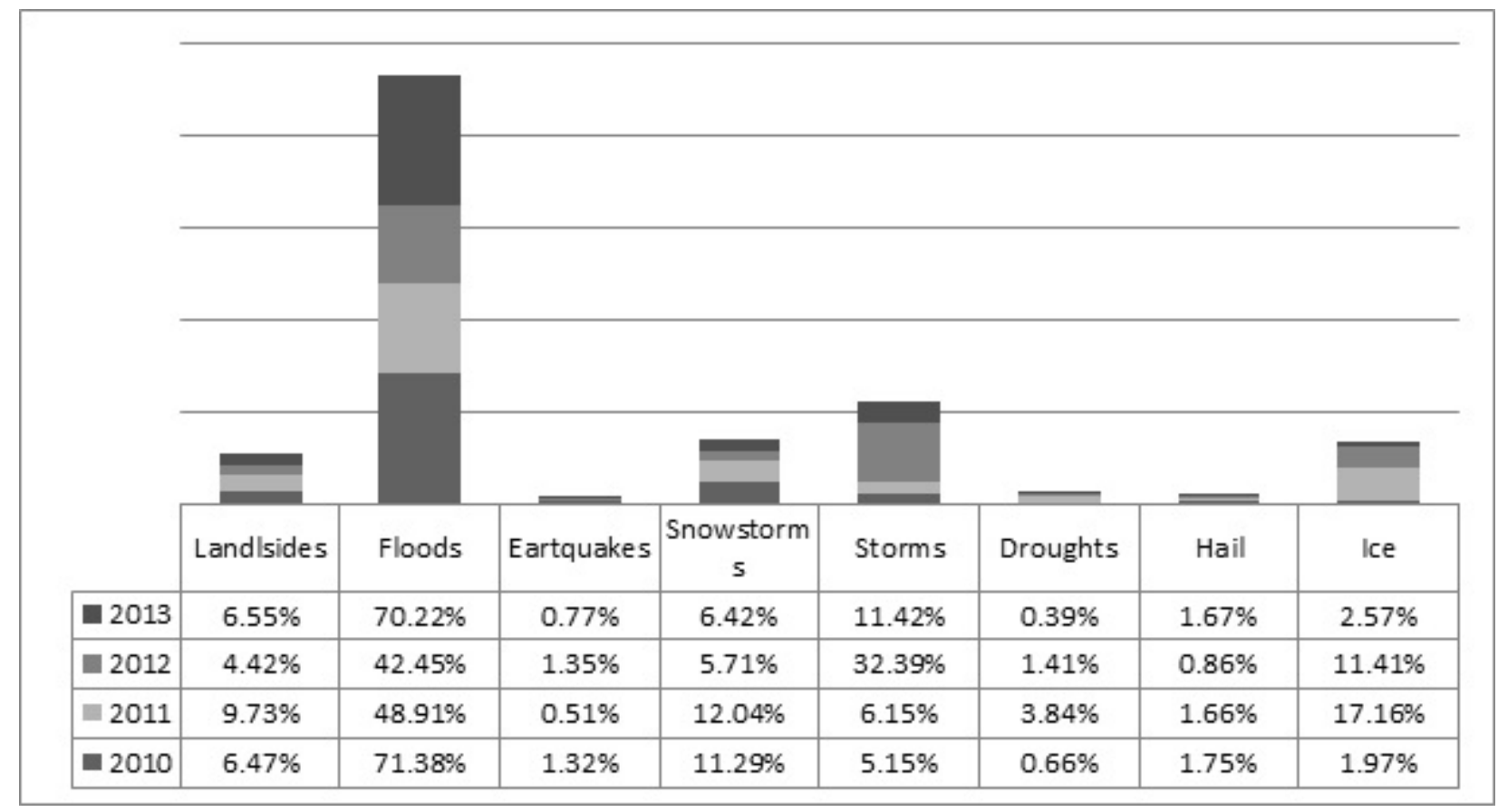

Figure 3. Natural disasters by type 2010-2013

Currently, on national level, the most common way for dealing with floods are structural measures. Such measures are dams, river strengthening, etc. Problems with dams have been established in many places around the world. The case in Bulgaria is that on one hand most of these structures are obsolete and pose real danger to society. For example, according to data provided by the East Aegean River
Basin Directorate (Figure 4) $18 \%$ of the floods which took part between 2005-2012 are due to failure of protective structures. On the other hand, when dams are to provide protection against floods, their reservoir should be empty. Still, very often the reservoir is kept full for other reasons as fishing and irrigation. Therefore multiobjective use of water in dams is a complex technological problem (3).

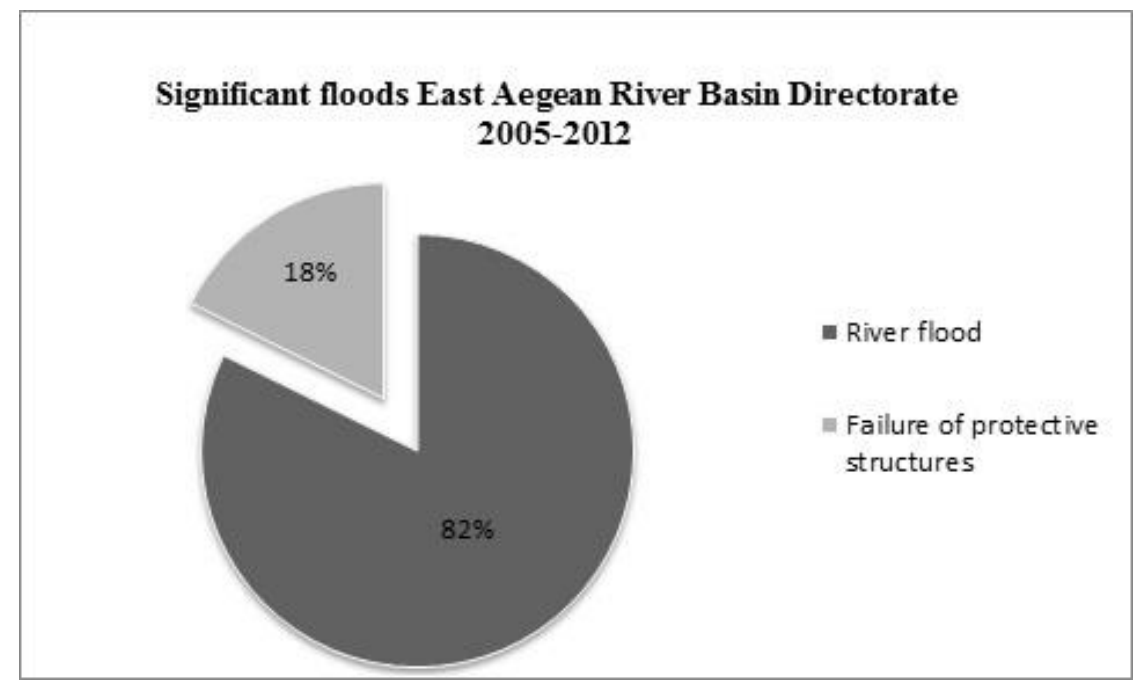

Figure 4. Reason for occurrence of floods

According to the Water Law the protection against floods includes mainly structural measures (building of levees, river strengthening), maintaining good conductivity of rivers, measures against erosion and alert systems. Recently proposed measures (March 2015) by the government considering flood risk are limited to only measures connected with dams' safety and technical condition in the country. Considering the fact that the prevailing measures for managing floods are structural, it is obvious that the sustainability approach is missing. Nevertheless, all these measures have their role on flood management. 
But their place should be very thoroughly examined, as they appear to be effective in the occurrence of small floods. Therefore, other more sustainable measures should be added in the package of flood management.

Moreover, considering the requirements adopted by the Flood Directive, each member state should consider not only structural measures for flood protection, but also areas which have the potential to retain flood water, such as natural floodplains (4).

\section{ACHIEVING SUSTAINABILITY USING NATURE}

TODOROVA K.

Natural Water Retention Measures represent type of green infrastructure which aims at increasing natural capacity to cope with flood risk. As part of the natural type of measures it requires the use of ecosystem services for providing sustainable flood risk management.

Therefore, one way to involve the sustainability in flood management is using the ecosystem approach. It is very likely that this type of measures are more cost-effective in the long-term compared with traditional structural measures such as building dams, dikes, etc. Moreover, it has great impact on local biodiversity and green corridors (5). Practices which can lead to water regulation and flood storage are described in Table 1.

Table 1. Types of NWRMs

\begin{tabular}{|c|c|}
\hline Field of intervention & Type of NWR measure \\
\hline \multirow{5}{*}{$\begin{array}{c}\text { Agriculture \& } \\
\text { Forestry }\end{array}$} & Maintenance of buffer strips \\
\hline & Restoration of pastures and green cover \\
\hline & Sustainable soil practices \\
\hline & Afforestation \\
\hline & Creation of riparian buffers \\
\hline \multirow{3}{*}{ River Catchment } & Restoration of floodplains \\
\hline & Removal of riverbank protection where possible \\
\hline & Reconnection of meanders \\
\hline \multirow{4}{*}{ Urban sites } & Permeable paving \\
\hline & Green roofs\& rain gardens \\
\hline & Infiltration trenches \\
\hline & Retention ponds \\
\hline
\end{tabular}

Engaging with sustainable approach for flood management requires not only working with nature but also finding the right synergies across different policy sectors on EU level. Therefore, an integrated approach must be pursued, involving types of measure which contribute to the Common Arboricultural Policy. Elements of ecological focus areas set out in the Commission proposal for greening the CAP Pillar I, such as buffer strips, could serve as natural retention measures, thus achieving targets in priority fields in EU policy.

During the last years research has been made on the benefits of using ecosystem services, such as flood regulation. To put a price on ecosystem service which has no obvious value to society is one way to present what nature gives in order to sustain our life. Different analyses have been performed in order to show the monetary value of floodplains in extreme events regulation. The monetary value of the provision of ecosystem service such as 
regulation of water flows of inland wetlands appears to be $5606 \$ /$ ha/year (2007 price levels) and it appears to be one of the best biomes for regulation of floods (6). Finding the economically viable and socially justice way to decrease flood risk is not an easy task however. The East Aegean River Basin Directorate in its Preliminary Flood Risk Assessment has found exemplary retention lowlands which could serve as natural retention surfaces. Their total area is 5422 ha (7). Most of these territories are farmlands. Estimating the avoided cost of an extreme event and finding the efficient and effective way to perform natural water retention measure should lead to benefits in both social and economic aspects.

\section{GENERAL CONCLUSIONS}

Based on the analyses the following conclusions can be made:

- Sustainable flood risk management requires an alternative approach for flood risk reduction and diminishing consequences after an extreme event;

- Natural water retention measures can be seen as one way to manage flood risk in sustainable approach, i.e. working with nature not against it;

- Natural retention measures could be seen as additional to structural measures;
Nevertheless, more research is needed in the implementation part of these measures, mainly to display the mutual benefits which they can bring to other EU policy sector. Further research is needed for gaining better knowledge specifically on the costeffectiveness and efficiency on different types of NWRMs in the context of flood risk reduction in Bulgaria.

\section{REFERENCES}

1. Commission of the European Communities, Mainstreaming sustainable development into EU policies: 2009 Review of the European Union Strategy for Sustainable Development, 2009

2. Commission of the European Communities, White paper on Adaptation to Climate Change, 2009

3. Swedish Research Council Formas, Dams under Debate, 2006

4. European Parliament and Council, Flood Directive 2007/60/EC, 2007

5. Rudolf de Groot, Global estimates of the value of ecosystems and their services in monetary units, Ecosystem Services 1 (2012) 50-61, 2012

6. EU Commission, Natural Water Retention Measures, technical report, 2014

7. East Aegean River Basin Directorate, Preliminary Flood Risk Assessment report, 2013 